A comprehensive memoir on the geology and ore-deposits of the Bisbee Quadrangle, Arizona, by Mr. F. L. Ransome, appears as one of the "professional papers " of the United States Geological Survey (1904). This district became famous for its production of copper-ore in 1880 , and was connected with the railway system as recently as 1902 . Hence Mr. Ransome has found himself obliged to invent names-and pleasing ones of Spanish origin-for several topographic features. His plates show how the geological structure of the country can be read on many of the hillsides with the clearness of a diagram; in several respects they remind one of the bare dry landscapes in the Mesozoic areas of the Basses Alpes. The fossiliferous beds include Middle Cambrian, Devonian (apparently conformable on these), Lower and Upper Carboniferous (both marine), and Cretaceous, resting unconformably on the preceding beds. The affinities of the strata are with those of Texas. The paper concludes with a discussion of the origin of the copperores, in which stress is laid on their concentration from cupriferous iron-pyrites, deposited in metamorphosed limestone.

In the Proceedings of the Royal Society of Victoria (vol. xvii., n.s., part i.) Messrs. F. Chapman and G. B. Pritchard commence an article on the fossil fish-remains from the Tertiaries of Australia. They deal with the description, range in time, and distribution of the sharks, and they observe that Asteracanthus, hitherto known only from Secondary strata, extended beyond question into the Tertiary seas round southern Australia. In other articles the Silurian Ostracoda and Phyllocarida, and the Tertiary Polyzoa and Mollusca of Victoria receive attention. Prof. J. W. Gregory contributes a paper on the antiquity of man in Victoria, and concludes (contrary to his previously expressed opinion) that, however ancient the Australian aborigines may be, there is no evidence of the long occupation of Victoria by man.

We have received the annual report of the Geological Survey of Canada for the year 1900, issued in 1903; it is accompanied by geological maps, dated 1904, of parts of British Columbia. (Atlin Gold-fields), Labrador, Saskatchewan, and Quebec.

A revision of the Palæozoic Palæechinoidea, with a synopsis of all known species, has been contributed by Mary J. Klem (Trans. Acad. Science, St. Louis, vol. xiv., No. I). She remarks that the prevailing characters which may be taken as a basis for classification are :-(I) number of columns in the ambulacra; (2) position and number of the ambulacral pores; (3) ornamentation of the plates; (4) imbrication of the plates; (5) apical system; (6) general shape of the body; and (7) geological position.

An interesting article on the occurrence and distribution of copper in the United States, by Mr. W. H. Weed, appears in the Mining Magazine (New York, September). Nearly 700 million pounds of metallic copper were produced in the States during 1903, and in the previous year nearly 300 million pounds were obtained from an area a mile long and half a mile wide at Butte, in Montana, where the Anaconda Mine produces more copper than any other mine in the world. The ores occur in well defined veins in quartzmonzonite, associated with white granite or aplite, which forms dykes and small masses. Dykes of quartz-porphyry also occur, and seem to have some genetic association with the ore-bodies. Several mines are 2200 feet deep.

The Geological Survey of Queensland has commenced the issue of Records. In No. I Mr. B. Dunstan, the acting Government geologist, contributes notes on the occurrence of gold nuggets near Mount Morgan, on phosphate-bearing rocks, asbestos, oriental rubies, \&c. Mr. R. Etheridge records the occurrence of Halysites in the Chillagoe limestones. We have received also Publications Nos. Igr and 192 , on the tin, copper, and silver mining in the Stanthorpe district, by Lionel C. Ball, and on the Herberton tin field, by Mr. W. E. Cameron.

Some Upper Devonian fish-remains, obtained by Dr. Whitman Cross from Colorado, are described by Mr. C. R. Eastman (Amer. Journ. Sci., October). The remains belong to the genera Bothriolepis and Holoptychius. In the same journal a number of fossil turtles belonging to the Marsh collection in Yale University Museum are described and figured by Mr. O. P. Hay. Many of the specimens are from the Laramie deposits of Wyoming.

\section{SCIENTIFIC RESEARCH IN THE PHILIPPINE ISLANDS.}

THE occupation of the Philippine Islands by the United States has been quickly followed by the establishment of laboratories, and already a large amount of scientific work has been done, and several valuable reports have been issued.

The report ${ }^{1}$ under review deals with the year ending September, 1903. The permanent buildings of the Government laboratory at Manila were completed last April, and comprise a serum laboratory for the preparation of therapeutic sera and vaccine lymph with attached paddocks and animal houses, a chemical laboratory, a biological department for the prosecution of pathological, entomological, and botanical research, a marine biological station, a bureau of weights and measures, and a library.

About one-third of the volume is occupied with a report on trypanosomiasis by Dr. Musgrave and $\mathrm{Mr}$. Clegg, with special reference to the existence of surra among the horses in the Philippines. At the same time a very complete review of our present knowledge of trypanosomiasis is given, the various species are described, and the symptomatology and prophylaxis are discussed. The report, which is a very valuable one, is copiously illustrated with excellent photographs, temperature charts, \&c. Several other papers of pathological interest are included in the volume; also an. account of rinderpest inoculation.

Another valuable report is on the gutta-percha industry. and the various gutta-percha-producing trees, and is illustrated with a number of photographs of species of Palaquium and Payena, methods of collection of the guttapercha, maps of geographical distribution, \&c.

The final third of the volume contains the report of $\mathrm{Mr}$. Charles Banks, the Government entomologist, and gives an account of the insect pests attacking the cacao. This, like the rest of the papers, is copiously illustrated with excellent photographs.

The volume reflects the greatest credit on the staff of the laboratory, but the complete omission of a table of contents and an index should be remedied in future issues.

R. T. Hewlett.

\section{UNIVERSITY AND EDUCATIONAL INTE LLIGENCE.}

Birmingham.-A chair of music has been established by an endowment of $10,000 l$. given for that purpose by $\mathrm{Mr}$. Richard Peyton, of Birmingham. The chair has been accepted by Sir Edward Elgar; but the intention of the university authorities is by no means to interfere in any way with his work as composer, and he will be left free to develop the chair gradually and on such lines as he, in consultation with other members of the Senate, may think fit.

Dr. Arthur Robinson, of King's College, London, has been elected to the chair of anatomy, vacated by the appointment of Dr. Windle to the presidency of Queen's College, Cork. The new professor will assume office in January.

A new chair of electrical engineering has been established as a supplement to the lectureship in the same subject held by Dr. D. K. Morris. The first occupant of the chair will be $\mathrm{Mr}$. Gisbert Kapp, now lecturer at Charlottenburg. He is not expected, however, to return to this country until the autumn of next year, and his appointment will not take effect until October, 1905. Meanwhile, and subsequently, Dr. Morris and his staff will continue their work as before. The new and large buildings for the department will be ready by that time. A competent assistant will have to be elected to assist Prof. Kapp in the drawing office for dynamo and central station design.

Prof. Burstall will continue to occupy his chair, the title of which will be changed to "Mechanical Engineering," and he will have control over a great engineering block and the power station.

It is not improbable that a special chair of civil engineering in the narrower sense will be established.

1 Report of the Superintendent of Government Laboratories in. the Philippine Islands for the Year ended September $x$, rgo3. 
Edingurgh.--Sir Donald Currie has subscribed the sum of 25 ,oool. toward the fund which is being raised by the sniversity to enable a site to be purchased on which laboratories and other educational buildings could be erected, and for making further financial provision for an extension of the teaching staff and for the promotion of research in the university. To the principal, Sir William Turner, Sir Donald Currie stated that he wished the revenue from this money to be applied by the university court to the remuneration of a staff of lecturers, such as the authorities of the university might find it advisable from time to time to appoint. An option was also given to the university court to apply $5000 l$. of the amount towards the purchase of a site for the new laboratories, should it be necessary to use a portion of his gift for that purpose. In addition to this gift, subscriptions amounting to $15,000 l$. have been promised by other friends of the university.

According to a report mentioned in Science, it is proposed to move the Western University of Pennsylvania from the suburbs of Allegheny to Pittsburg proper, near the new Carnegie Technical School. About fifty acres of ground, sufficient for twenty large university buildings, are being secured at a cost of about $400,000 l$, and the work of construction will be begun before long. Fifty citizens of Pittsburg have agreed to give each from $8000 l$. to $20,000 l$. for the school. From the same source we learn that the general assembly of the State of Vermont has appropriated $12,000 l$. for the use of the agricultural department of the university. The money is to be expended in the erection and equipment of a building to be known as Morrill Agricultural Hall, in memory of the father of the agricultural colleges of the country, the late Senator Justin S. Morrill.

IT may be remembered that the authorities of University College, Sheffield, were informed by the committee of the Privy Council that, subject to a substantial realisation of the hopes entertained in connection with the movement for the establishment of a Sheffield University, their Lordships would be prepared in due course to recommend to His Majesty the grant of a charter. We learn from the calendar of the University College for 1904-5 that of the sum of $170,000 l$., which efforts are being made to raise, 54,1347 . has been promised since 1903. In addition, 52,908l. was promised in 1902 to the new buildings fund, so that some 107,042l. has been raised for higher education in Sheffield within a short period. It is to be hoped that little difficulty will be experienced in securing the amount which must be provided still before the University of Sheffield can be incorporated.

Two technical State scholarships have been just placed at the disposal of the local government of the Punjab, says the Pioneer Mail. These scholarships will enable natives of India to pursue a course of study in Great Britain or other western countries with the object of qualifying them to assist in promoting the improvement of existing native industries and the development of new industries wherever this may be possible. In the case of the Punjab the industries allowed to be taken up are tanning, metalwork, and pottery, and the local government has decided to confine its efforts to the first two, at any rate for the present. The value of each scholarship has been fixed at I $50 l$. a year, and it will be tenable for two years, but it will be open to the Government of India to increase the value of any scholarship, and to extend the period during which it will be tenable. Commissioners and superintendents of divisions have been asked to make the scheme publicly known, and to enlist in its behalf the interest of the commercial classes.

THE annual prize distribution and students' conversazione at the Northampton Institute, E.C., was held last week, when the prizes and certificates were distributed by Lord Reay. The principal's report showed that the work of the institute has in several important departments overtaken the accommodation, and that there is urgent necessity for extension. A special note was made of the recent recognition of the work of the institute by the Board of Education; and the necessity for a "British Institute of Technical Optics" was pointed out. Lord Reay, in his address, dwelt upon the desirability of reviving, so far as modern conditions would allow, the old system of apprenticeship, and pointed out how the polytechnics and technical institutes could be made useful in connection therewith. The vote of thanks to Lord Reay was moved by Mr. Alexander Siemens. After the distribution the various laboratories and workshops were thrown open, and a series of lecturettes, exhibits, and demonstrations was given. The most interesting demonstration was perhaps that of a new submersible boat in the swimming bath. These boats, invented by $\mathrm{Mr}$. Middleton, of Brighton, are propelled, directed, controlled, and governed by fins actuated by prime movers, in such a fashion that they can move any way in tri-dimensional space in the fluid in which they are immersed. By altering the inclination of the plane of the fins, these can be made to propel the boat forwards or backwards, to sink it below the surface, to raise it again, and, in fact, to direct it along any course, whether inclined to the horizontal or otherwise.

THE proceedings of the Institute of Chemistry of Great Britain and Ireland for I904, which have now been pub. lished, show that the council of the institute has had under consideration the recommendations of the Consultative Committee to the Board of Education for a scheme of examinations for school certificates. It will be remembered that it is proposed that these school certificates should take the place of the many professional preliminary examinations now held; that a central board should be constituted for England, consisting of representatives of the Board of Education and of the different examining bodies, to control the standard of the examinations for school certificates; and that the proposed examinations should be under the control of independent external examiners, although conducted by internal and external examiners jointly. The council of the Institute of Chemistry has informed the Board of Education $(a)$ that the council considers it desirable to substitute some such system as is proposed in lieu of the various professional preliminary examinations now held; (b) that if such a system be established, the council will be prepared to accept the proposed senior certificate examination, passed in the subjects required by the regulations of the institute; and (c) that the council will be pleased to be represented on the proposed central board. A scheme for school certificates submitted by the University of Birmingham has also met with the approval of the council of the institute, and it has also been decided to accept the matriculation examination held jointly by the Victoria University, the University of Liverpool, and the University of Leeds, as an approved preliminary examination, provided the certificate include the subjects required by the regulations of the institute.

A Deputation from the Association of Chambers of Commerce of the United Kingdom waited upon Lord Londonderry, President of the Board of Education, on Monday to urge that increased Government aid should be giveri to higher technical and higher commercial education. The views of the deputation were expressed in the following resolution, which was passed at the meeting of the association on September 28, and was now laid before Lord Londonderry :- "That, in order to retain our industrial position and to introduce into this country such further industries as may be profitably developed, this association is of opinion that it is absolutely necessary to establish or acquire public secondary schools of the highest standard, where efficient tneans of such education do not exist, with fees low enough to make them accessible to all grades, and to provide sufficient inducements by bursaries, exhibitions, scholarships, or otherwise to make the efficient boys stay long enough in these schools in order to thoroughly train and adequately prepare a very much larger number than is at present available for taking full advantage of the provisions made for higher technical and higher commercial education, the facilities for which ought also to be largely extended and the standard considerably raised." In introducing the deputation, Sir W. H. Holland, M.P., said the chambers of commerce might be fairly taken to represent the organised commercial opinion of the country, and they were convinced that the Board of Education would encourage them to take a keen interest in secondary and technical education. $\mathrm{Mr}$. Ivan Levinstein said the want of secondary education was the cause of our present most deplorable position. What we wanted, in the first instance, was a far larger number of 
high-class public secondary schools. We must be prepared to face a great financial sacrifice, for some years at any rate, if we were to put secondary education in this country on anything like the level it had reached in America, Switzerland, and Germany. After other speakers had put forward similar claims for consideration of the subject, Lord Londonderry, in reply, said that he felt the weight of the arguments put forward, but the opinions of his colleagues of the Board of Education and himself on this vitally important matter were expressed in such detail and so definitely in the reply forwarded by Mr. Morant to the chamber on September 26 (see NATURE, October I3, p. 595) that on the present occasion he proposed to devote attention rather to the question of commercial education than to that of technical education. The whole matter was one to which the Board were fully alive, and he was very glad to learn from the representations which they had made that day that there was on the part of the chambers of commerce a keen appreciation of the value of that special advanced instruction in the several sections of mercantile practice which the Board had felt it their duty to encourage in the evening schools serving the more important commercial communities.

\section{SOCIETIES AND ACADEMIES. LONDON.}

Royal Society, February II.- "On Certain Properties of the Alloys of Silver and Cadmium." By Dr. T. K. Rose.

Attention was directed to these alloys on account of the advantages of using them as the material for trial plates for testing the fineness of silver coin and plate. An examination of the curves of equilibrium between the liquid and solid states of the alloys proved the existence of several compounds of silver and cadmium, some of which have already been recognised in other ways. Horizontal branches of the curve mark the solidification of the compounds $\mathrm{Ag}_{3} \mathrm{Cd}_{2}, \mathrm{AgCd}$, and $\mathrm{AgCd}$, and the solidification of $\mathrm{Ag}_{2} \mathrm{Cd}_{3}$ corresponds to a cusp on the curve of initial freezing points.

There is a strong tendency for mixtures of the compounds to form solid solutions. This is strikingly shown in the case of alloys containing more than 80 per cent. of silver. At temperatures in the short range of a few degrees between the initial and final freezing points of these alloys, two bodies exist side by side, but at a lower temperature they coalesce to form a single solid solution provided that sufficient time is allowed for complete mixing by diffusion. For example, in the standard alloy, which contains 7.5 per cent. of cadmium, solidification begins at about $945^{\circ}$, and is completed at about $913^{\circ}$. If the alloy is maintained at some temperature between these points a network of a silverpoor body is gradually formed surrounding crystals of a silver-rich body. If the alloy is subjected for some hours to a temperature a little below $913^{\circ}$, large crystals with regular boundaries are formed occupying the whole area of the field. These alloys are remarkably ductile.

The alloy corresponding to the formula $\mathrm{Ag}_{2} \mathrm{Cd}$ is finegrained and apparently homogeneous. If heated for some time to a temperature of $750^{\circ}$, somewhat below its point of solidification, the cadmium from the surface is volatilised, leaving a layer of pure silver. On removing this during the operation of polishing a black layer is met with, coloured by oxide of cadmium, and underneath this the original alloy is found to exist. The layers are not everywhere of the same thickness, so that in the course of polishing alternate rings of black and white are produced, resembling the well known Japanese decorative metal-work called Mokumé, which is used in jewellery.

The alloy containing about 50 per cent. of silver consists of crystals of a silver-rich body, often pinkish in colour, set in a white matrix composed of $\mathrm{AgCd}_{3}$. The 40 per cent. alloy is a hard, brittle substance, the compound $\mathrm{Ag}_{2} \mathrm{Cd}_{3}$. As the percentage of silver decreases, a matrix, consisting mainly of $\mathrm{AgCd}_{3}$, makes its appearance surrounding the crystals of $\mathrm{Ag}_{2} \mathrm{Cd}_{3}$, and specimens containing less than 25 per cent. of silver consist of crystals of $\mathrm{AgCd}_{3}$ set in a matrix of cadmium.

Several similarities to the silver-zinc series of alloys have been noted.

NO. I 833 , VOL. $7 \mathrm{I}]$
November 24.- "The Refractive Indices of the Elements." By Clive Cuthbertson.

In a letter addressed to Nature in October, 1902, attention was directed to the fact that the refractivities of the five inert gases of the atmosphere, $\mathrm{He}, \mathrm{Ne}, \mathrm{A}, \mathrm{Kr}$, and $\mathrm{X}$, as determined by Ramsay and Travers, were, within narrow limits of accuracy, in the proportion of $1,2,8,12$ and 20 ; or, more simply, of $\frac{1}{4}, \frac{1}{2}, 2,3$, and 5 .

In a second letter it was shown that the refractivities of the halogens, $\mathrm{Cl}, \mathrm{Br}$, and $\mathrm{I}$, stand also in the relation of 2,3 , and 5 to the same degree of accuracy; but it was pointed out that the figures for $\mathrm{P}, \mathrm{As}$, and $\mathrm{S}$, as measured by $M$. Le Roux in $186 \mathrm{r}$, did not show any similar relation; and it was observed that a re-determination of them would be interesting.

With a Jamin's refractometer, adapted for use with high temperatures, results have now been obtained for $\mathrm{Hg}, \mathrm{P}$, and $\mathrm{S}$, which differ widely from those of M. Le Roux. The index of mercury, calculated for a molecule containing two atoms, is placed at $\mathrm{I} \cdot 001857$, a number which agrees closely with the value given by the refractive equivalent of Gladstone. The index of $\mathrm{P}_{2}$ is found to be 1.001197 , and that of $\mathrm{S}_{2}$ is $\mathrm{r}$.0or ror.

In all three cases it is estimated that the margin of error does not exceed $x^{\frac{1}{2}}$ per cent. Comparing these values for $\mathrm{P}_{2}$ and $\mathrm{S}_{2}$ with those of $\mathrm{N}_{2}$ and $\mathrm{O}_{2}$, it is shown that the simple relations found in the case of the inert gases and the halogens also hold in the case of nitrogen and phosphorus, oxygen and sulphur; and that an atom of phosphorus retards light four times as much as an atom of nitrogen, an atom of sulphur four times as much as an atom of oxygen.

Efforts have also been made to measure the index of fluorine in the gaseous state, but, owing to the experimental difficulties, success has not yet been attained.

It appears then, that, out of fourteen elements the index of refraction of which has been measured in the gaseous state, twelve conform to the rule that in each chemical group the refractivities of the elements are in the ratios of small integers. The other two, $\mathrm{Hg}$ and $\mathrm{H}$, have no allied elements with which they can be compared.

It is pointed out that $\mathrm{N}, \mathrm{O}$, and $\mathrm{Ne}$ are each followed, in their respective families, by an element the refractivity of which is four times as great, and that, consequently, there are reasons for believing that the elements composing the series $\mathrm{N}, \mathrm{O}, \mathrm{F}$, and $\mathrm{Ne}$, and $\mathrm{P}, \mathrm{S}, \mathrm{Cl}$, and $\mathrm{A}$ are, in some sense, homologous. Comparing the refractivities of the latter series we see that the power to retard light appears to be closely connected with the valency, increasing as it increases, in spite of the decrease in atomic weight, as shown in the following table :-

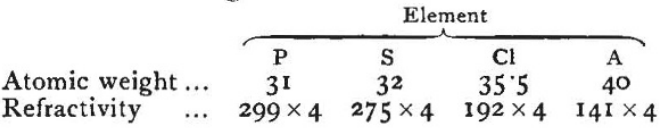

The series $\mathrm{Ne}, \mathrm{O}, \mathrm{N}$, show the same relation, and it is probable that the refractivity of $\mathrm{C}$ is even higher than that of $\mathrm{N}$.

The refractivity of $\mathrm{B}$, estimated from $\mathrm{BCl}_{3}$ and $\mathrm{BBr}_{3}$, is certainly very great; but whether it exceeds that of $\mathrm{C}$ there is not sufficient evidence to determine.

December I.-." On the Structure and Affinities of Fossil Plants from the Palæozoic Rocks.-V. On a New Type of Sphenophyllaceous Cone (Sphenophyllum fertile) from the Lower Coal-measures." By Dr. D. H. scott, F.R.S.

The class Sphenophyllales, of which the fossil described is a new representative, shows on the one hand clear affinities with the Equisetales, while on the other it approaches the Lycopods; some botanists have endeavoured to trace a relation to the ferns. The nearest allies among recent plants are probably the Psilotaceæ, which some writers have even proposed to include in the Sphenophyllales.

The new strobilus appears to find its natural place in the type-genus Sphenophyllum, as at present constituted, but it possesses peculiar features of considerable importance, which may probably ultimately justify generic separation. The specimen, of which a number of transverse and longitudinal sections have been prepared by Mr. Lomax, is from one of the calcareous nodules of the Lower Coal-measures 